\title{
Brief of Amicus Curiae 290 Criminal Law and Mental Health Law Professors in Support of Petitioner's Request for Reversal and Remand, Kahler v. Kansas, 18-6135 (U.S. June 6, 2019)
}

Paul F. Rothstein

Georgetown University Law Center, rothstei@law.georgetown.edu

Docket No. 18-6135

This paper can be downloaded free of charge from:

https://scholarship.law.georgetown.edu/facpub/2243

https://ssrn.com/abstract=3548091

Brief of Amicus Curiae 290 Criminal Law and Mental Health Law Professors in Support of Petitioner's Request for Reversal and Remand, Kahler v. Kansas, 18-6135 (U.S. June 6, 2019).

This open-access article is brought to you by the Georgetown Law Library. Posted with permission of the author. Follow this and additional works at: https://scholarship.law.georgetown.edu/facpub

Part of the Constitutional Law Commons, Criminal Law Commons, Law and Philosophy Commons, Law and Psychology Commons, Medical Jurisprudence Commons, Psychiatric and Mental Health Commons, and the Psychiatry and Psychology Commons 


\title{
IN THE
}

\section{Wureme Court of the flinited States}

\author{
JAMES K. KAHLER,
}

Petitioner,

$\mathrm{v}$.

STATE OF Kansas,

Respondent.

On Writ of Certiorari to the

Supreme Court of Kansas

\section{BRIEF OF AMICUS CURIAE 290 CRIMINAL LAW AND \\ MENTAL HEALTH LAW PROFESSORS \\ IN SUPPORT OF PETITIONER'S REQUEST FOR REVERSAL AND REMAND}

\author{
STEPHEN J. MORSE \\ Ferdinand Wakeman \\ RICHARD J. BONNIE \\ Counsel of Record \\ Hubbell Professor of Law \\ Professor of Psychology and \\ Law in Psychiatry \\ UNIVERSITY OF \\ PENNSYLVANIA \\ LAW SCHOOL \\ 3501 Sansom Street \\ Harrison Foundation Professor \\ of Law and Medicine \\ Professor of Psychiatry And \\ Neurobehavioral Sciences \\ UNIVERSITY OF VIRGINIA \\ SCHOOL OF LAW \\ Philadelphia, PA 19104-6204 \\ (215) 898-2562 \\ 580 Massie Road \\ smorse@law.upenn.edu \\ Charlottesville, VA 22903-1789 \\ (434) 924-3209 \\ rbonnie@virginia.edu \\ Counsel for Amici Curiae
}




\section{QUESTION PRESENTED}

Do the Eighth and Fourteenth Amendments permit a state to abolish the insanity defense? 
TABLE OF CONTENTS

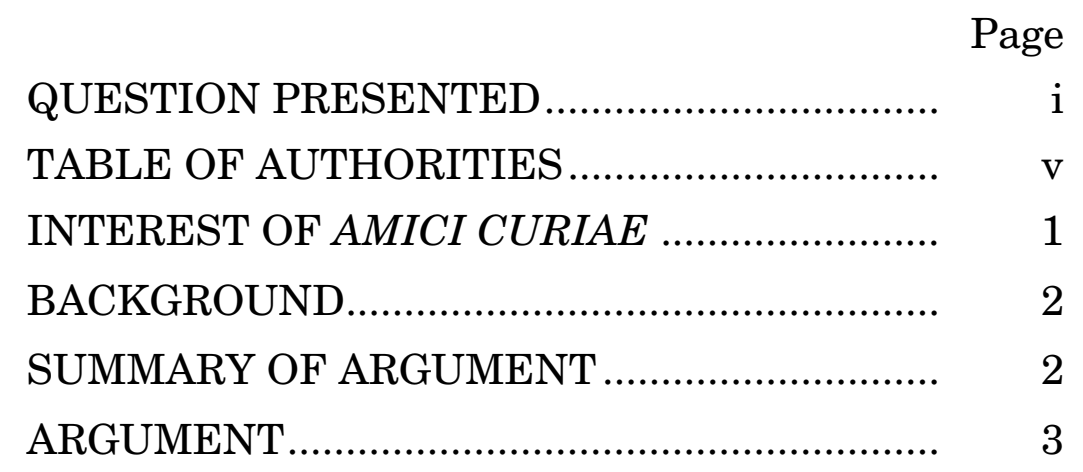

I. THE AFFIRMATIVE DEFENSE OF LEGAL INSANITY EXPRESSES FUNDAMENTAL LEGAL PRINCIPLES LONG RECOGNIZED BY THE COMMON LAW, STATE AND FEDERAL STATUTES AND THE JURISPRUDENCE OF THIS COURT ...

A. The Legal and Moral Necessity of the Legal Insanity Defense ....................... 3

B. The Test for Legal Insanity.................. 8

II. ADMITTING MENTAL DISORDER EVIDENCE TO NEGATE MENS REA OR TO MITIGATE THE SENTENCE ARE INADEQUATE SUBSTITUTES FOR THE INSANITY DEFENSE

A. The Mens Rea Alternative................... 11

B. Sentencing .......................................... 17

III. THE OBJECTIONS TO THE INSANITY DEFENSE ARE TOO INSUBSTANTIAL TO JUSTIFY ABOLITION ....................... 
iv

TABLE OF CONTENTS-Continued

Page

A. Assessing Past Mental State Using Psychological and Psychiatric Evidence.............................................. 18

B. Public Safety ........................................ 19

C. Indeterminacy of the Legal Insanity Tests ..................................................... 20

D. Fraudulent Claims .............................. 21

CONCLUSION ................................................ 23

APPENDIX

List of Amici Curiae ........................................ 1a 


\section{$\mathrm{V}$ \\ TABLE OF AUTHORITIES}

CASES

Page(s)

Atkins v. Virginia, 536 U.S. 304 (2002)

6

Clark v. Arizona, 548 U.S. 735 (2006) $5,9,18$

Drope v. Missouri, 420 U.S. 162 (1975)

Finger $v$. State, 27 P. 3d 66 (Nev. 2001)

Ford v. Wainwright, 477 U.S. 399 (1986)

Foucha v. Louisiana, 504 U.S. 71 (1992)

Godinez v. Moran, 509 U.S. 389 (1993).

7

In re Winship, 377 U.S. 358 (1970)

Indiana v. Edwards, 534 U.S. 164 (2008)

7

Jones $v$. U.S., 463 U.S. 354 (1983) .................................. 16, 20

Kansas v. Crane, 534 U.S. 407 (2002).

M'Naghten's Case, 8 Eng. Rep. 718 (1843) $4,10,12,13$

Madison v. Alabama, 139 S. Ct. 718 (2019) 
vi

TABLE OF AUTHORITIES-Continued

Page(s)

Panetti v. Quarterman, 551 U.S. 930 (2007).

People v. Serravo, 823 P. 2d 828 (Colo. 1992) (en banc) ....... 13

Powell v. Texas, 392 U.S. 514 (1968).............................. 9

Roper $v$. Simmons, 534 U.S. 551 (2005)

State v. Kahler, 410 P.3d 105 (Kan. 2018).

\section{CONSTITUTION}

U.S. Const. amend. XIV passim

\section{OTHER AUTHORITIES}

1 Nigel Walker, Crime and Insanity in England (Edinburgh Univ. Press 1968)...

Abraham S. Goldstein, The Insanity Defense (Yale Univ. Press 1967)...............

Brian E. Elkins, Idaho's Repeal of the Insanity Defense: What Are We Trying to Prove?, 31 Idaho L. Rev. 151 (1994).........

Deborah W. Denno, Who is Andrea Yates? A Short Story About Insanity, 10 Duke J. Gender L. \& Pol'y 1 (2003)

George F. Parker, Outcomes of Assertive Community Treatment in an NGRI Conditional Release Program, 32 J. Am. Acad. Psychiatry \& L. 291 (2004). 
vii

TABLE OF AUTHORITIES-Continued

Page(s)

Henry J. Steadman et al., Factors Associated With a Successful Insanity Plea, 140 Am.J. Psychiatry 401 (1983)

Herbert Fingarette \& Ann Hasse, Mental Disabilities and Criminal Responsibility (Berkeley University of California Press 1979)

Lisa A. Callahan et al., Revocation of Conditional Release: A Comparison of Individual and Program Characteristics across Four States, 21 Int'l J.L. \& Psychiatry 177 (1998)

Lisa Callahan et al., The Hidden Effects of Montana's "Abolition" of the Insanity Defense, 66 Psychiatric Q. 103 (1995) ......

Marc Rosen, Insanity Denied: Abolition of the Insanity Defense in Kansas, 8 Kan. J. L. \& Pub. Pol'y 253 (1998)

Mark R. Wiederanders et al., Forensic Conditional Release Programs and Outcomes in Three States, 20 Int'l J.L. \& Psychiatry 249 (1997)

Michael K. Spodak et al., Criminality of Discharged Insanity Acquittees: Fifteen Year Experience in Maryland Reviewed, 12 Bull. Am. Acad. Psychiatry L. 373 (1984) 
viii

TABLE OF AUTHORITIES-Continued

Page(s)

Michael L. Perlin, "The Borderline Which Separated You from Me": The Insanity Defense, the Authoritarian Spirit, the Fear of Faking, and the Culture of Punishment," 82 Iowa L. Rev. 1375 (1997).

Michael S. Moore, Law and Psychiatry (Cambridge Univ. Press 1984)

Nat'l Mental Health Ass'n, Myths and Realities: A Report of the Nat'l Comm'n on the Insanity Defense (1983)..................

Oliver Wendell Holmes, Jr., The Common Law (Little, Brown \& Co. 1945) (1881)....

Richard A. Pasewark, Insanity Pleas: A Review of the Research Literature, $9 \mathrm{~J}$. Psychiatry \& Law 357 (1981).

Richard J. Bonnie, John C. Jeffries, Jr., \& Peter W. Low, A Case Study in the Insanity Defense: The Trial of John W. Hinckley, Jr. (3rd. ed 2008).

Richard J. Bonnie, The Moral Basis of the Insanity Defense, 69 A.B.A. J. 194 (1983) ..

Richard Moran, Knowing Right From Wrong: The Insanity Defense Of Daniel McNaughtan (2000)

Stephen J. Morse, Mental Disorder and Criminal Law, 101 J. Crim L. \& Criminology 885 (2011) $4,12,20$ 
ix

TABLE OF AUTHORITIES-Continued

Page(s)

Stephen J. Morse, Undiminished Confusion in Diminished Capacity, 75 J. Crim. L. \& Criminology 1 (1984)

Stephen M. LeBlanc, Comment, Cruelty to the Mentally Ill: An Eighth Amendment Challenge to the Abolition of the Insanity Defense, 56 Am. U. L. Rev. 1281 (2007)...

Thomas Maeder, Crime and Madness: The Origins and Evolution of the Insanity Defense (Harper \& Row 1985) 


\section{INTEREST OF AMICI CURIAE ${ }^{1}$}

Amici curiae are a group of philosophically and politically diverse law school professors and scholars in the fields of criminal law and mental health from a variety of disciplines who have been teaching and writing about the insanity defense and related issues throughout their careers. They include the authors of leading criminal law and mental health law treatises and casebooks and numerous important scholarly books and articles.

Amici believe this case raises important questions about principles of criminal responsibility, the integral role of the insanity defense in Anglo-American law, and the inadequacy of the "mens rea alternative" to the traditional affirmative defense. Their teaching and research on the subject have given them a unique appreciation of the historical and doctrinal significance of the defense of legal insanity.

A complete list of amici who reviewed and join in this brief is included in the attached Appendix.

Amici file this brief solely as individuals and not on behalf of any institution with which they are affiliated. Affiliations are provided solely for the purpose of identification.

\footnotetext{
${ }^{1}$ No counsel for a party authored this brief in whole or in part, and no party or counsel for a party made a monetary contribution intended to fund its preparation or submission. No person other than amici made a monetary contribution to the preparation or submission of this brief. The parties were given timely notice and have consented to this filing.
} 


\section{BACKGROUND SUMMARY OF ARGUMENT}

The affirmative defense of legal insanity has such a strong historical, legal, moral and practical pedigree and is so widely accepted that providing such a defense is a matter of fundamental fairness in a just society. Jurisdictions have substantial leeway in deciding what test best meets their legal and moral policies, but some form of affirmative defense is a prerequisite of justice and therefore is required under the Due Process clause.

Legal insanity gives doctrinal expression to fundamental legal and moral principles that have been recognized by the common law and statute for centuries and that this Court has repeatedly acknowledged. Punishment under the penal law is not justified unless an offender can fairly be held criminally responsible for his conduct. There is no dispute that severe mental disorder can strongly affect an individual's cognitive and self-regulation capacities and that in extreme cases, the defects are sufficiently grave to negate any attribution of fault because such offenders do not know, understand or appreciate the wrongfulness of their actions. Criminal blame and punishment are fundamentally unfair because such offenders are not responsible for their criminal conduct. Aside from four states in our country, some form of the insanity defense is universal in United States law, as well as in every other jurisdiction in the common law world.

The alternative to the insanity defense at issue in this case, which permits evidence of mental abnormality to be introduced to negate the mens rea for the crime charged, is insufficient to achieve the goal of responding justly to severely mentally disordered 
offenders. In most cases, mental disorder, including severe mental disorder, does not negate mens rea. Instead, the offender's disordered cognition gives the offender the reason to form the mens rea required by the definition of the offense. Although an offender may act for reasons entirely detached from reality through no fault of his own, the offender will almost always be exposed to conviction of the most serious crime charged. These are profoundly unjust results.

Because Kansas has abolished the defense of insanity, the defendant had no opportunity for a factual determination regarding the severity of his mental disorder and its impact on his ability to appreciate the wrongfulness of his behavior. Accordingly, this Court should reverse the conviction and remand the case to the Supreme Court of Kansas to take appropriate action to reinstate the insanity defense.

\section{ARGUMENT}

I. THE AFFIRMATIVE DEFENSE OF LEGAL INSANITY EXPRESSES FUNDAMENTAL LEGAL PRINCIPLES LONG RECOGNIZED BY THE COMMON LAW, STATE AND FEDERAL STATUTES AND THE JURISPRUDENCE OF THIS COURT

This section provides the positive argument in favor of providing an insanity defense. It then considers the leeway of jurisdictions to establish a test for legal insanity that comports with the justice goals of individual jurisdictions.

\section{A. The Legal and Moral Necessity of the Insanity Defense}

It is a fundamental principle of justice that if an offender was not responsible for his crime, blame and 
punishment under the penal law are fundamentally unfair and thus a violation of Due Process. The affirmative defense of legal insanity applies this fundamental principle by excusing those mentally disordered offenders whose disorder or intellectual disability deprived them of rational understanding of their conduct or, in a minority of states, by excusing offenders whose capacity to control their conduct at the time of the crime was profoundly and severely impaired. Michael S. Moore, Law and Psychiatry (Cambridge Univ. Press 1984); Herbert Fingarette \& Ann Hasse, Mental Disabilities and Criminal Responsibility (Berkeley Univ. of California Press 1979); Stephen J. Morse, Mental Disorder and Criminal Law, 101 J. Crim L. \& Criminology 885, 925 (2011).

This principle is simple but profound. Indeed, in recognition of this, the insanity defense has been a feature of ancient law and of English law since the 14th Century. Thomas Maeder, Crime and Madness: The Origins and Evolution of the Insanity Defense (Harper \& Row 1985); 1 Nigel Walker, Crime and Insanity in England (Edinburgh Univ. Press 1968); Brian E. Elkins, Idaho's Repeal of the Insanity Defense: What Are We Trying to Prove?, 31 Idaho L. Rev. 151, 161 (1994). The predominant modern test for legal insanity dates to the 19th Century with M'Naghten's Case, 8 Eng. Rep. 718 (1843), but some form of an affirmative defense of legal insanity existed many centuries before that. A small number of states tried to abolish the insanity defense in the early part of the twentieth century, but their state supreme courts found these attempts unconstitutional. Stephen M. LeBlanc, Comment, Cruelty to the Mentally Ill: An Eighth Amendment Challenge to the Abolition of the Insanity Defense, 56 Am. U. L. Rev. 
1281, 1289 n.45 (2007). Thus, the insanity defense was universal in the United States from the founding until the last decades of the 20th Century. Abraham S. Goldstein, The Insanity Defense (Yale Univ. Press, 1967); Clark v. Arizona, 548 U.S. 735 (2006). Despite the recent deviation from this longstanding principle by four states, a strong consensus still supports retention of the insanity defense, as was thoroughly explained by the Supreme Court of Nevada in 2001, when that court held that the legislature's effort to abolish the defense was a violation of due process under both the state and federal constitutions. Finger v. State, 27 P. 3d 66 (Nev. 2001). The insanity defense is firmly rooted in the legal history and traditions of the United States.

In both law and morals, the capacity for reason is the primary foundation for responsibility and competence. The precise cognitive deficit a person must exhibit can of course vary from context to context. In addition, many believe that the capacity to regulate one's own behavior properly, to be able to control one's conduct, is also a foundation for responsibility. In the criminal justice system, an offender who lacks the capacity to understand the wrongness of his actions as the result of severe mental disorder - a condition that is not the offender's fault-may not be convicted and punished.

Under a parallel body of law in many jurisdictions, a defendant who is profoundly unable to regulate his behavior is regarded as undeserving of full blame and punishment and must be excused in a sufficiently extreme case. Moreover, it is generally acknowledged that offenders in these two categories cannot be deterred because the rules of law and morality cannot adequately guide them. Failing to excuse severely 
impaired mentally disordered offenders is inconsistent with both retributive and deterrent theories of just punishment.

Legally insane offenders are not excused solely because they suffered from a severe mental disorder at the time of the crime. The mental disorder must also impair their ability to know, understand or appreciate that what they are doing is wrong or to impair some other functional capacity that a jurisdiction believes is crucial to responsibility. The crimes of those found legally insane do not result from bad judgment, insufficient moral sense, bad attitudes, or bad characters, none of which is an excusing condition. Rather, the crimes of legally insane offenders arise from a lack of understanding or lack of self-regulation capacity that is produced by severe mental abnormality and thus their criminal conduct is not reflective of culpable moral failure. To convict such people offends the basic sense of justice.

This Court has recently recognized that defects in the capacity for rationality and self-regulation preclude the most severe punishments for offenders with intellectual disability and juvenile offenders. Atkins v. Virginia, 536 U.S. 304 (2002) (intellectual disability); Roper v. Simmons, 534 U.S. 551 (2005) (juveniles). These defects exist along a continuum, ranging from mild to severe. In the cases involving intellectual disability and youth, the offenders were responsible to some degree, but in cases of more severe intellectual disability or developmental immaturity, holding such offenders responsible at all offends widely shared views about responsibility. The same principles apply to people with mental disorder. Although most people with mental disorder who commit crimes may be fully or partially responsible, 
in cases of severe disorder, the rationality and selfregulation defects this Court has recognized are so substantial that the offender is blameless and should not be held responsible. ${ }^{2}$

A similar baseline principle explains the many competence doctrines employed in the criminal justice process. This Court has long recognized that at every stage justice demands that some people with severe mental abnormalities must be treated differently from those without substantial mental impairment because some impaired defendants are incapable of reason and understanding in a specific context. Competence to stand trial, Drope v. Missouri, 420 U.S. 162 (1975); competence to plead guilty and to waive counsel, Godinez v. Moran, 509 U.S. 389 (1993); competence to represent oneself, Indiana $v$. Edwards, 534 U.S. 164 (2008); and competence to be executed, Ford v. Wainwright, 477 U.S. 399 (1986), Panetti v. Quarterman, 551 U.S. 930 (2007), Madison v. Alabama, 139 S. Ct. 718 (2019), are all examples in which the Constitution requires such special treatment. It is unfair and offensive to the dignity of criminal justice to treat people without understanding as if their understanding was unimpaired. Evidence of mental disorder is routinely introduced in all these contexts to determine if the defendant must be accorded special treatment.

The impact of mental disorder on an offender's responsibility and competence is recognized throughout the criminal law. Even the few jurisdictions that

${ }^{2}$ Note that the affirmative defense of legal insanity is the traditional doctrine by which people with marked intellectual disability can be fully excused. If the insanity defense were eliminated, most such offenders will form the requisite mens rea for the crime charged and will be punished despite lacking responsibility. 
have abolished the insanity defense, such as Kansas, recognize that mental disorder affects criminal responsibility because they permit the introduction of evidence of mental disorder to negate the mens rea for the crime charged and at sentencing. State $v$. Kahler, 410 P.3d 105, 124-25 (Kan. 2018). As Part II explains, however, this use of mental disorder evidence does not honor the principles concerning responsibility that are so deeply rooted in our legal history and tradition. As this Court has recognized, state infliction of stigmatization and punishment is a severe infringement, In re Winship, 377 U.S. 358, 363-64 (1970). It is unfair to prevent a defendant from proving, based on routinely admissible evidence, that he lacked rational understanding of his conduct, even if he formed the charged mens rea. That is precisely the issue Kahler raises.

Historical practice, the near universal acceptance of the need for an independent affirmative defense of legal insanity, and the fundamental unfairness of blaming and punishing legally insane offenders provide the strongest reasons to conclude that fundamental fairness and the Due Process clause require an insanity defense. Abolishing this narrowly defined and deeply rooted defense could plausibly be justified only if an alternative legal approach could reach the same just result or if irremediably deep flaws preclude fair and accurate administration of the defense.

The next two main sections of this brief argue that there are no such alternatives and that the defense is no more vulnerable to risks of mistake and abuse than any other disputed issue in the penal law.

\section{B. The Test for Legal Insanity}

This brief takes no position about what test for the affirmative defense of legal insanity any jurisdiction 
should adopt as long as the jurisdiction's rule permits defendants to raise defects resulting from severe impairments caused by mental disorder or intellectual disability that compromise the defendant's understanding of the wrongfulness of his criminal actions despite the presence of the mens rea required by the definition of the offense. This is as it should be. As Justice Marshall's plurality opinion in Powell v. Texas said,

We cannot cast aside the centuries-long evolution of the collection of interlocking and overlapping concepts which the common law has utilized to assess the moral accountability of an individual for his antisocial deeds. The doctrines of actus reus, mens rea, insanity, mistake, justification, and duress have historically provided the tools for a constantly shifting adjustment of the tension between the evolving aims of the criminal law and changing religious, moral, philosophical, and medical views of the nature of man. This process of adjustment has always been thought to be the province of the States.

Powell v. Texas, 392 U.S. 514, 535-36 (1968) (emphasis added).

Jurisdictions in our federal system have considerable constitutional leeway to decide what types of disorders and their consequent impairments are necessary to warrant a full legal excuse and what procedures should govern insanity defense cases. Indeed, in Clark, 548 U.S. 735, at 753-56, this Court approved Arizona's test for legal insanity, the nation's most limited rule.

Discussion in this brief has focused on lack of the capacity to know, appreciate or understand the wrongfulness of one's actions or to regulate one's 
behavior because, in one form or another, these deficits best explain the predominant tests adopted by forty-six states (including Arizona) and the federal criminal code. ${ }^{3}$ But how such lack of understanding or self-regulation should be defined doctrinally are matters within the province of the states and the federal government. Nevertheless, stigmatizing and punishing all severely disordered offenders, even those who were grossly out of touch with reality or seriously unable to regulate their conduct at the time of the crime is unjust. Such an offender is not a responsible agent, is not at fault, and only some defense of legal insanity can appropriately respond to this moral truth that has been recognized in law for centuries.

The Court should rule that the Due Process Clause prohibits criminal conviction and punishment of an offender who, as a result of mental disorder at the time

\footnotetext{
${ }^{3}$ All states that recognize the insanity defense have a "test" that is grounded in M'Naghten - (.i.e., that the defendant is not criminally responsible if he was unable to "know" the nature and quality of his conduct or unable to "know" that it was wrong). Much of the case law relates to the meaning of "knowing" that the act was "wrong." The meaning of this phrase was a major consideration in the drafting of the Model Penal Code insanity test, which states that a person is not criminally responsible if he lacked "substantial capacity" to "appreciate" the wrongfulness of the conduct. The MPC drafters omitted the "nature and quality of the act" part of M'Naghten because they regarded it as superfluous. The term "appreciation" was used to embrace the "affective" dimension of psychotic illness. It is designed to avoid conviction of a delusional defendant who was so detached from reality that he was unable to recognize the moral and emotional significance of his act. See generally, Richard J. Bonnie, John C. Jeffries, Jr., and Peter W. Low, A Case Study in the Insanity Defense: The Trial of John W. Hinckley, Jr. 12-14, 18-20 (3rd. ed 2008).
} 
11

of the offense, did not know, appreciate or understand the wrongfulness of his actions (or suffered from a comparable cognitive defect that equally undermines responsibility). Over the past century, many states and legal commentators have embraced the view that blame and punishment are also unfair in cases in which the offender's capacity to regulate his behavior at the time of the offense was profoundly severely impaired. Nevertheless, this view has never attracted an equivalent level of legislative and judicial support, and the court should, accordingly, leave the decision whether to recognize a defense in such cases to the individual states.

\section{ADMITTING MENTAL DISORDER EVI- DENCE TO NEGATE MENS REA OR TO MITIGATE THE SENTENCE ARE INADEQUATE SUBSTITUTES FOR THE INSANITY DEFENSE}

This section first addresses then "mens rea alternative" and then considers sentencing.

\section{A. The Mens Rea Alternative}

The negation of mens rea and the affirmative defense of legal insanity are different claims that preclude criminal liability by different means. The former denies the prima facie case of the particular crime charged; the latter is an affirmative defense that precludes liability in those cases in which the prima facie case is established. The post-verdict consequences are also different. The former leads to outright acquittal; the latter results in some form of involuntary civil commitment. Although in some cases the same mental disorder evidence may be used to prove the two different claims, they are not equivalent. 
12

The primary reason that permitting a defendant to introduce evidence of mental disorder to negate mens rea cannot justly replace the affirmative defense of legal insanity is that the mens rea alternative is based on a mistaken view of how severe mental disorder affects human behavior. In virtually all cases, mental disorder, even severe disorders marked by psychotic symptoms such as delusions and hallucinations, does not negate mens rea. Stephen J. Morse, Undiminished Confusion in Diminished Capacity, 75 J. Crim. L. \& Criminology 1, 16 (1984); Morse, Mental, supra, at 933. It is difficult to prove a negative, but cases, especially those involving serious crime, in which most or all mens rea is negated are rare to the vanishing point. Rather, mental disorder affects a person's motivations or reasons for committing the criminal acts. A mentally disordered defendant's irrationally distorted beliefs, perceptions or desires typically and paradoxically give him the motivation to form the mens rea required by the charged offense. Mental disorder rarely interferes with the ability to perform the necessary actions to achieve irrationally motivated aims. In cases of self-regulation problems, the defendant does form the mens rea but lacks substantial capacity to conform his conduct to the law.

Consider the following, typical examples, beginning with Daniel M'Naghten himself. M'Naghten's Case, 8 Eng. Rep. 718 (1843); M'Naghten delusionally believed that the ruling Tory party was persecuting and intended to kill him. Richard Moran, Knowing Right From Wrong: The Insanity Defense Of Daniel McNaughtan 10 (2000). As a result, he formed the belief that he needed to assassinate the Prime Minister, Peel, in order to end the threat. He therefore formed the intention to kill Peel. Thus, M'Naghten would have been convicted of murder if a defense of 
13

legal insanity was not available. Indeed, his case has come to stand for one of the "rules" enunciated by the House of Lords - that a defendant should be acquitted on grounds of insanity if he "was laboring under such a defect of reason, from a disease of the mind, as not to know the nature and quality of the act he was doing, or if he did know it, that he did not know he was doing what was wrong." 8 Eng. Rep. at 722.

For a more contemporary example, consider the case of Ms. Andrea Yates, the Texas woman who drowned her five children in a bathtub. She delusionally believed that she was corrupting her children and that unless she killed them, they would be tortured in Hell for all eternity. Deborah W. Denno, Who is Andrea Yates? A Short Story About Insanity, 10 Duke J. Gender L. \& Pol'y 1 (2003). She therefore formed the intention to kill them. Indeed, she planned the homicides carefully. Ms. Yates was nonetheless acquitted by reason of insanity because she did not know that what she was doing was wrong. Even if she cognitively recognized that her conduct violated the law of Texas and that she would be arrested, she was deeply convinced that the homicides were necessary to assure the eternal well-being of her children under the circumstances. In her psychotic thinking, everyone else would approve of her conduct as justified if they knew what she knew.

For a final example, suppose an offender hallucinates that he is hearing God's voice or delusionally believes that God is communicating with him and that God is commanding him to kill. E.g., People v. Serravo, 823 P. 2d 828, 830 (Colo. 1992) (en banc). If the offender kills in response to this "command hallucination" or delusion, he surely forms the intent to kill to obey the divine decree. Nonetheless, it would be 
14

unjust to punish this defendant because he, too, does not know right from wrong given his beliefs for which he is not responsible.

In all three cases, one could also claim that the defendant did not know what he or she was doing in a fundamental sense because the most material reason for action, what motivated them to form mens rea, was based on a delusion or hallucination that was the irrational product of a disordered mind. Finally, in all three cases the defendant's instrumental rationality, the ability rationally to achieve one's ends, was intact despite their severe disorders. They were able effectively to carry out their disordered plans.

There are very few contemporary data about the operation of the insanity defense and virtually none about the operation of the mens rea alternative. Montana is the only state for which there is a systematic study of mental disorder claims pre- and post-abolition of the insanity defense. The picture is complicated, but in brief, the number of cases, the types of defendants and the types of crimes did not change. There were two major effects, however. Under the mens rea alternative, more defendants were convicted and the number of defendants found incompetent to stand trial increased markedly. Lisa Callahan et al., The Hidden Effects of Montana's "Abolition" of the Insanity Defense, 66 Psychiatric Q. 103 (1995). Neither change is desirable. For the reasons given in Part I, supra, conviction is unjust in any case in which the defendant should have been acquitted by reason of insanity. The increase in convictions in Montana demonstrates that abolition of the insanity defense does, in fact, expose severely mentally ill offenders to unjust punishment. Moreover, the rise in the number of defendants found 
incompetent to stand trial who would previously have been found competent and acquitted suggests that an incompetency finding is being used as a tool for diversion in cases involving less serious charges that likely would have led to stipulated insanity acquittals under the pre-abolition statute. This is also objectionable.

Although Kahler seemed to have had the mens rea required for the charged offense of capital murder, his expert evidence established that he suffered from a number of mental disorders, including a major mental disorder, severe depression. As a result, the expert opined, Kahler's perception and judgment were so distorted that he may have become dissociated from reality at the time of the crime. The expert also testified that Kahler could not refrain from his conduct. Because an insanity defense was not available and Kahler's conduct met the criteria for capital murder, his conviction for the most serious crime in the criminal law was improperly a foregone conclusion.

To further understand the injustice of the mens rea alternative, consider a case in which mens rea may plausibly be negated. Suppose a defendant charged with murder claims that he delusionally believed that his obviously human victim of a shooting was in reality the devil and not a human being. See Richard J. Bonnie, The Moral Basis of the Insanity Defense, 69 A.B.A. J. 194, 195-96 (1983). If his beliefs were genuine, the defendant did not intentionally kill a human being. Indeed, in a mens rea alternative jurisdiction, he could not be convicted of purposely, knowingly or recklessly killing a human being because his delusional beliefs negated all three mental states. After all, he fully believed that he was shooting at the 
devil, not a human being. The defendant would be convicted of negligent homicide, however, because the standard for negligence is objective reasonableness and the motivating belief was patently unreasonable.

Of course, convicting the severely disordered defendant of a crime based on a negligence standard is fundamentally unjust, as even Mr. Justice Holmes recognized in his rightly famous essays on the common law. Oliver Wendell Holmes, Jr., The Common Law 50-51 (Little, Brown \& Co. 1945) (1881). The defendant's unreasonable mistake was not an ordinary mistake caused by inattention, carelessness or the like. Defendants are responsible for the latter because we believe that they had the capacity to behave more reasonably by being more careful or attentive. In contrast, the hypothetical defendant's delusional "mistake" was the product of a disordered mind and thus he had no insight and no ability to recognize the gross distortion of reality. He was a victim of his disorder, not someone who deserves blame and punishment as a careless perpetrator of involuntary manslaughter. He does not deserve any blame and punishment, and only the defense of legal insanity could achieve this appropriate result. Paradoxically, such a defendant's potential future dangerousness if he remains deluded would be better addressed by an insanity acquittal and indefinite involuntary commitment, a practice this Court has approved, Jones $v$. U.S., 463 U.S. 354 (1983), than by the comparatively short, determinate sentences for involuntary manslaughter.

Thus, the mens rea alternative is not an acceptable replacement or substitute for the insanity defense. Only in the exceedingly rare case in which mental disorder negates all mens rea would the equivalent 
justice of a full acquittal be achieved, albeit for a different reason. But again, this is the rarest of cases. Most legally insane offenders form the mens rea required by the definition of the charged offense and only the defense of legal insanity can respond justly to their lack of blameworthiness.

\section{B. Sentencing}

Consideration of mental disorder for purposes of assessing both mitigation and aggravation is a staple of both capital and non-capital sentencing, but it is no substitute for the affirmative defense of legal insanity. On moral grounds, it is unfair to blame and punish a defendant who deserves no blame and punishment at all, even if the offender's sentence is reduced. Blaming and punishing in such cases is unjust, full stop. Sentencing judges might also use mental disorder as an aggravating consideration because it might suggest that the defendant is especially dangerous as a result. Thus, sentences of severely mentally ill offenders might be enhanced. Again, injustice would result, and indeterminate post-acquittal comment would better protect public safety than enhanced sentences. Third, unless a sentencing judge is required by law to consider mental disorder at sentencing, whether the judge does so will be entirely discretionary. Again, this is a potent, potential source of injustice. In short, only a required insanity defense would insure that arguably blameless mentally disordered offenders have an opportunity to establish that state blame and punishment are not justified. 
18

\section{THE OBJECTIONS TO THE INSANITY DEFENSE ARE TOO INSUBSTANTIAL TO JUSTIFY ABOLITION}

A number of objections to the insanity defense have been raised by proponents of abolition, including Kansas, but they are insubstantial and provide not even a rational basis for abolishing a defense with such a profound historical, legal, and moral basis. See Marc Rosen, Insanity Denied: Abolition of the Insanity Defense in Kansas, 8 Kan. J. L. \& Pub. Pol'y 253, 25560 (1998). They certainly cannot survive a more demanding standard of review. In general, these objections relate to supposed difficulties of administering the insanity defense fairly and accurately. Specific objections include: (A) administering the defense requires an assessment of the defendant's past mental state using controversial psychiatric and psychological evidence, a task that is too difficult; (B) acquitting insane defendants endangers public safety; $(\mathrm{C})$ the indeterminacy of the defense produces arbitrary verdicts; and (D) it invites fraudulent claims by defendants trying to "beat the rap."

\section{A. Assessing Past Mental State Using Psychological and Psychiatric Evidence}

It is often difficult to reconstruct past mental states and, as this Court has acknowledged, psychological and psychiatric evidence can be problematic. Clark, 548 U.S. at 740-41; Kansas v. Crane, 534 U.S. 407, 413 (2002). Nevertheless, all jurisdictions, including mens rea alternative jurisdictions, concede the necessity of proving mens rea (for most crimes) before punishment may justly be imposed. Consequently, the argument against the insanity defense based on the difficulty of reconstructing past mental states must fail unless 
assessing past intent, knowledge, and other types of mens rea is easier than assessing whether the defendant was acting under the influence of severely abnormal mental states. After all, both mens rea and legal insanity refer to past mental states that must be inferred from the defendant's actions, including utterances. The severe disorder that is practically necessary to support an insanity defense is arguably easier to prove than ordinary mens rea.

Despite the problems with mental health evidence, all but four jurisdictions that have abolished the insanity defense believe that assessing legal insanity at the time of the crime with mental health evidence is possible. Indeed, it is routine. Moreover, even the four abolitionist jurisdictions permit introduction of such evidence to negate mens rea. Unless abolitionist jurisdictions are prepared to argue-and none hasthat assessing mens rea with mental health evidence is uniquely reliable, the argument based on the deficiencies of mental health evidence lacks credibility. Finally, mental health evidence is routinely admitted in a vast array of civil and criminal contexts, including all the criminal competencies and sentencing.

\section{B. Public Safety}

As previously argued, the insanity defense poses no danger to public safety. Successful insanity defenses are so rare that deterrence will not be undermined because few legally sane defendants will believe that they can avoid conviction by manipulatively and falsely raising the defense. More important, every jurisdiction provides for commitment to a secure mental facility after a defendant has been acquitted by reason of insanity and this Court has approved the constitutionality of indefinite confinement (with 
periodic review) of such acquittees as long as they remain mentally disordered and dangerous. Jones, 463 U.S. 354; Foucha v. Louisiana, 504 U.S. 71 (1992); Morse, Mental, supra, at 932. Further, this Court has approved procedures for the commitments that are more likely to result in continued confinement of acquittees than standard civil commitment. Jones, 463 U.S. 354. It is of course true that acquittees might be released earlier than if they had been convicted and imprisoned, but there is no evidence that released acquittees pose a special danger to the community. Michael K. Spodak et al., Criminality of Discharged Insanity Acquittees: Fifteen Year Experience in Maryland Reviewed, 12 Bull. Am. Acad. Psychiatry L. 373, 382 (1984); Mark R. Wiederanders et al., Forensic Conditional Release Programs and Outcomes in Three States, 20 Int'l J.L. \& Psychiatry 249, 249-257 (1997); Lisa A. Callahan et al., Revocation of Conditional Release: A Comparison of Individual and Program Characteristics across Four States, 21 Int'l J.L. \& Psychiatry 177 (1998); George F. Parker, Outcomes of Assertive Community Treatment in an NGRI Conditional Release Program, 32 J. Am. Acad. Psychiatry \& L. 291, 291-303 (2004); Henry J. Steadman et al., Factors Associated With a Successful Insanity Plea, 140 Am.J. Psychiatry 401, 402-03 (1983).

\section{Indeterminacy of the Insanity Tests}

Unlike many other criteria for criminal liability, the insanity defense tests do not raise strictly factual questions. Rather, the judgment made about the defendant's mental state at the time of the crime is primarily a legal, moral, and social judgment. For example, whether the defendant fired the fatal bullet and intended to kill the victim, thus satisfying the elements of murder, are factual questions with 
21

determinate, albeit often difficult to determine, answers. By contrast, the insanity defense tests ask indeterminate questions, such as how much understanding of right and wrong a defendant must have in order to be acquitted (or, in the minority of states that also have a control test, how substantially their capacity to control their conduct was impaired). Of course, the legal judgment must be based on facts, but the legal test is normative and not factual. The insanity defense tests prescribe the relevant behavioral continuum, but drawing the line between guilt and innocence is the task of the finder of fact as the legal and moral representative of the community. Except at the extremes, there are rarely determinate answers to such questions. Although decisions about normative criteria can be difficult, decisions about legal insanity are no more challenging (and probably more determinate) than judgments about reasonableness or recklessness that finders of fact routinely make.

\section{Fraudulent Claims}

Few defendants who are actually legally sane in some objective sense "beat the rap" with the insanity defense. Experts using the proper diagnostic tools can reliably distinguish people who are faking major mental disorder. Michael L. Perlin, "The Borderline Which Separated You from Me": The Insanity Defense, the Authoritarian Spirit, the Fear of Faking, and the Culture of Punishment, 82 Iowa L. Rev. 1375, 1409-16 (1997) Further, it is best estimated that the insanity defense is raised in less than one percent of federal and state trials and is rarely successful. Nat'l Mental Health Ass'n, Myths and Realities: A Report of the Nat'l Comm'n on the Insanity Defense 14-15 (1983); Richard A. Pasewark, Insanity Pleas: A Review of the 
Research Literature, 9 J. Psychiatry \& Law 357, 36166 (1981).

The complaint that the availability of the defense of legal insanity allows large numbers of guilty criminals to avoid conviction and punishment is simply unfounded. Prosecutors and defense attorneys alike generally recognize that insanity is a defense of last resort that betokens an otherwise weak defense and that rarely succeeds. Insanity acquittals are far too infrequent to communicate the message that the criminal justice system is "soft" or fails to protect society. It is impossible to measure precisely the symbolic value of these acquittals, but it is also hard to believe that they have much impact on social or individual perceptions. So few insanity pleas succeed that neither aspiring criminals nor society assume that conviction and punishment will be averted by raising the defense.

And, of course, if the defendant is legally insane and succeeds with the defense, he deserves to be acquitted and has not "beaten the rap" at all.

The "tough on crime" justification that underlies this argument is based on a fundamental misconception about the meaning of an insanity acquittal. In cases of a successful insanity defense, the prima facie case for guilt has been established and the verdict thus announces that the defendant's conduct was wrong. Nonetheless, the defendant did not deserve blame and punishment and will be confined by commitment. 


\section{CONCLUSION}

Until the latter part of the Twentieth Century, all American jurisdictions had some version of the insanity defense. Even now, only four states have abolished the defense. The historical practice and continuing consensus favoring retention of the defense reflect a longstanding legal and moral judgment that it is unfair and unjust to blame and punish criminal defendants who lacked the capacity to understand or appreciate the wrongness of their actions. This proposition is so rooted in our legal and moral traditions and culture that this Court should recognize its constitutional status. Further, there is no alternative that will achieve equal justice by other means. Finally, the policy reasons that might override the fairness concerns are insufficient. Accordingly, we urge the Court to rule that the insanity defense is so deeply rooted in our nation's legal traditions and is so fundamental to justice that it may not be abolished.

Respectfully submitted,

STEPHEN J. MORSE
Ferdinand Wakeman
Hubbell Professor of Law
Professor of Psychology and
Law in Psychiatry
UNIVERSITY OF
PENNSYLVANIA
LAW SCHOOL
3501 Sansom Street
Philadelphia, PA 19104-6204
(215) 898-2562
smorse@law.upenn.edu

\author{
RICHARD J. BONNIE \\ Counsel of Record \\ Harrison Foundation Professor \\ of Law and Medicine \\ Professor of Psychiatry And \\ Neurobehavioral Sciences \\ UNIVERSITY OF VIRGINIA \\ SCHOOL OF LAW \\ 580 Massie Road \\ Charlottesville, VA 22903-1789 \\ (434) 924-3209 \\ rbonnie@virginia.edu
}

Counsel for Amici Curiae

June 6, 2019 
APPENDIX 
1a

\section{APPENDIX}

\section{List of Amici Curiae}

John Felipe Acevedo is Visiting Lecturer of Law at the University of Alabama Culverhouse School of Law. He writes about criminal justice.

Akin Adepoju is Adjunct Professor at Widener University Delaware Law School, where he teaches courses in advanced criminal law and Eighth Amendment, and studies and practices extensively in the area of law and mental health.

Janet Ainsworth is John D. Eshelman Professor of Law at Seattle University, where she teaches criminal procedure and criminal law.

Lawrence Alexander is Warren Distinguished Professor of Law and Co-Executive Director of the Institute for Law \& Religion at the University of San Diego School of Law. He has written numerous books and articles on criminal law and philosophy.

Jose' Felipe' Anderson is Professor of Law at the University of Baltimore School of Law. He was an appellate public defender (Supervising Attorney) in Maryland who routinely addressed mental state issues and he now teaches criminal law and procedure.

Peter Arenella is Professor of Law Emeritus at UCLA Law School. He taught criminal law, criminal procedure, and testified before Congress concerning proposed legislation to either abolish or contract the scope of the insanity defense in federal jurisdictions.

Jennifer Arlen is Norma Z. Paige Professor of Law at New York University School of Law. She teaches in the criminal area and has expertise in the psychology of responsibility. 
$2 \mathrm{a}$

Robert Aronson is Betts, Patterson Professor of Law Emeritus at the University of Washington. He has taught criminal law, evidence and professional responsibility.

Hadar Aviram is Thomas Miller '73 Professor of Law at UC Hastings. She teaches criminal justice and civil rights.

Barbara Babcock, a former defense attorney, is Crown Prof. Emerita, Stanford Law School, where she taught criminal justice.

Cheryl G. Bader is Associate Clinical Professor of Law Fordham University. A former AUSA, she is currently teaching an interdisciplinary Criminal Defense Clinic that collaborates with Ph.D. candidates in Fordham's Forensic Psychology program.

W. David Ball is Associate Professor at the Santa Clara School of Law and Co-Chair of the Corrections Committee of the American Bar Association.

Brook K. Baker is Professor of Law at Northeastern University School of Law. He teaches disability rights.

Susan A. Bandes is Centennial Professor of Law Emeritus at DePaul University College of Law. She has written extensively in the fields of criminal law, criminal procedure, and law and psychology.

Rachel E. Barkow is the Vice Dean and Segal Family Professor of Regulatory Law and Policy and the Faculty Director of the Center on the Administration of Criminal Law at NYU School of Law.

Loftus Becker is Professor of Law Emeritus at the University of Connecticut School of Law. He taught and wrote about criminal law, constitutional law, and law and psychology and psychiatry from 1972 to 2018. 
$3 a$

Valena Beety is Professor of Law at the Sandra Day O'Connor College of Law Arizona State University. She teaches criminal law, criminal procedure, postconviction remedies, and her scholarship focuses on wrongful convictions.

Adam Benforado is Professor of Law at the Drexel University Kline School of Law. He teaches criminal law and law and mind sciences, and his research is focused on law and psychology.

Michael J. Benza is Senior Instructor of Law at Case Western Reserve University, School of Law. He teaches criminal law and constitutional criminal procedure with special focus on the death penalty and prisoners' rights, and has represented death row inmates for over 20 years.

Vera Bergelson is Professor of Law and Robert E. Knowlton Scholar at Rutgers School of Law-Newark. She writes extensively about criminal law.

Mitchell Berman is the Leon Meltzer Professor of Law, and Professor of Philosophy, at the University of Pennsylvania. He teaches and writes in criminal law and constitutional law.

William W. Berry III is Associate Professor of Law at the University of Mississippi School of Law. He teaches criminal law, is a co-author of a criminal law textbook (Criminal Law, Carolina Academic Press, 9th edition), and has written extensively about the death penalty and the Eighth Amendment.

Donald N. Bersoff is Professor of Law Emeritus at Drexel Law School, where he taught mental health law. He is a member of the Board of Trustees of the Bazelon Center for Mental Health Law. 
$4 \mathrm{a}$

Guyora Binder is SUNY Distinguished Professor of Law and Vice Dean for Research at the University at Buffalo School of Law, SUNY. He is author of The Oxford Introductions to U.S. Law: Criminal Law, and many works on culpability, punishment theory, and homicide law.

Christopher Blakesley is Professor Emeritus at Louisiana State University and at the University of Nevada Las Vegas, where he is also a Barrick Distinguished Scholar.

John H. Blume is the Samuel F. Leibowitz Professor of Trial Techniques at Cornell Law School where he teaches criminal procedure, evidence and federal appellate practice. Most of his scholarship explores issues related to intellectual disability, mental illness and impairment and capital punishment.

Susanna L. Blumenthal is William Prosser Professor of Law and Professor of History at the University of Minnesota. She teaches criminal law and has written extensively about the history of criminal responsibility and medico-legal conceptions of insanity.

Ted Blumoff is Professor of Law at Mercer University School of Law. He writes extensively on mental disorder and criminal responsibility.

Richard Boldt is T. Carroll Brown Professor of Law at the University of Maryland Carey School of Law. He teaches mental health law and criminal law and has published significant scholarship on criminal responsibility.

Richard J. Bonnie is Harrison Foundation Professor of Law and Medicine, Professor of Psychiatry and Neurobehavioral Sciences, Professor of Public Policy, and Director of the Institute of Law, Psychiatry and Public Policy at the University of Virginia. He is 
$5 \mathrm{a}$

coauthor of a leading casebook, Criminal Law (4th ed 2015), and, A Case Study in the Insanity Defense: The Trial of JohnW. Hinckley, Jr. (3rd ed 2008).

Vincent Martin Bonventre is the Justice Robert H. Jackson Distinguished Professor of Law at Albany Law School, Albany, NY. He teaches criminal procedure and constitutional law and has written and lectured extensively about criminal law and constitutional law subjects.

Deborah L. Borman, who is also a social worker, is Assistant Professor of Law at the University of Arkansas, Little Rock. She has extensive experience as both an attorney and social worker with people with mental disorder.

Bruce A. Boyer is Curt and Linda Rodin Professor of Law and Social Justice at Loyola University of Chicago School of Law. He is the Director of Loyola's Civitas ChildLaw Clinic and his responsibilities include teaching criminal law.

Shawn Boyne is Professor of Law at the Indiana University Robert H. McKinney School of Law. She is a former prosecutor who teaches criminal law and criminal procedure and has written extensively on prosecutorial decision-making.

Frank A. Bress is Professor of Law, Director of Clinical Programs and Acting Director of Clinical and Experiential Learning at New York Law School. He has taught a criminal defense clinic and related criminal law and criminal procedure courses and has interposed an insanity defense in many homicide cases.

Katherine S. Broderick is Dean Emerita and Joseph Raul Chair of Social Justice at the University of the District of Columbia David A. Clarke School of Law. 
$6 a$

She is former director of the criminal defense clinic for 10 years, member of the Access to Justice Commission.

William M. Brooks is Clinical Professor of Law at Touro College Jacob D. Fuchsberg Law Center. He teaches mental health law and has both litigated on behalf of and written extensively about the rights of people with mental illness.

Darryl Brown is O.M. Vicars Professor of Law at the University of Virginia School of Law.

John Burkoff is Professor of Law Emeritus at the University of Pittsburgh. He has taught courses in criminal law for many years in the United States and other countries, and has written extensively about criminal law and criminal responsibility.

Catherine Greene Burnett is Associate Dean and Professor of Law at South Texas College of Law Houston. Her clinical work involves post-conviction remedies that often raise mental health issues.

Catherine L. Carpenter is The Hon. Arleigh M. Woods and William T. Woods Professor of Law at Southwestern Law School. She writes extensively in the area of sex crimes and sex offense registration laws.

Jenny Carroll is the Wiggins, Childs, Quinn, and Pantazis Professor of Law at the Culverhouse School of Law, University of Alabama. She teaches criminal law and criminal procedure and has written extensively about calculation of criminal culpability

Linda Carter is Professor of Law Emerita at the University of the Pacific, McGeorge School of Law. She taught criminal law and criminal procedure for over 30 years and also published on criminal procedure issues. 
$7 \mathrm{a}$

Timothy Casey is Professor in Residence and Director of the STEPPS Program at California Western School of Law. He teaches and writes about legal ethics, and criminal law and procedure.

Rosanna Cavallaro is Professor of Law at Suffolk University Law School. She teaches and writes about criminal law.

Carol A. Chase is Professor Emerita at Pepperdine Law School where she taught criminal law, criminal procedure, evidence and trial practice. She is a former federal prosecutor.

Kami Chavis is Professor Law and Director of the Criminal Justice Program at Wake Forest and a former AUSA in the District of Columbia. She teaches criminal law.

Gabriel J. Chin is Edward L. Barrett Jr. Chair and Martin Luther King Jr. Professor of Law at the University of California, Davis School of Law. He teaches and has written extensively about constitutional criminal law and procedure.

Morgan Cloud is Charles Howard Candler Professor of Law at Emory University School of Law. He has taught and written about criminal law and procedure for 36 years.

John C. Coffee, Jr. is Adolf A. Berle Professor at Columbia Law School, where he teaches criminal law and white collar crime.

James A. Cohen is Associate Professor of Law at Fordham University School of Law.

Marjorie Cohn is professor emerita at Thomas Jefferson School of Law, where she taught criminal law, criminal procedure and evidence. 
$8 a$

Doug Colbert is Professor of Law at the Maryland Francis King Carey School of Law. He has been teaching criminal law for 35 years.

Dana K. Cole is Associate Professor of Law at the University of Akron School of Law. He teaches criminal law, evidence, and trial advocacy.

Kevin Cole is Professor of Law at the University of San Diego, where he teaches criminal law and procedure. $\mathrm{He}$ is the editor of the CrimProf Blog and has written on the topic of criminal responsibility and practical limits in litigating about it.

Beth A. Colgan is an Assistant Professor of Law at UCLA School of Law, where she teaches criminal law. She writes about proportionality and punishment.

Anna G. Cominsky is a Visiting Associate Professor of Law at New York Law School where she teaches and supervises the Criminal Defense Clinic. She has been practicing criminal defense work for 13 years.

John Copacino is Professor of Law at Georgetown University Law Center. He has been the Director of the Criminal Justice Clinic at Georgetown for 32 years and has practiced criminal law for 40 years.

Michael Louis Corrado is Arch Allen Distinguished Professor of Law Emeritus at the University of North Carolina Law School. He has written extensively on criminal responsibility.

Robert J. Cottrol is Harold Paul Green Research Professor of Law and Professor of History and Sociology at The George Washington University Law School. He has taught criminal law for over 30 years.

Anne M. Coughlin is Lewis F. Powell, Jr., Professor of Law at the University of Virginia School of Law. She teaches criminal law and criminal procedure, she is 
$9 \mathrm{a}$

the co-author of a criminal law casebook, and she has written a number of articles about criminal responsibility.

Aliza Plener Cover is Associate Professor at the University of Idaho College of Law. She teaches and writes about criminal law, criminal procedure, and the death penalty.

Randall Coyne is Frank Elkouri and Edna Asper Elkouri Professor of Law Emeritus at the University of Oklahoma College of Law

Phyllis L. Crocker is Professor of Law and Dean at University of Detroit Mercy School of Law. She has taught criminal law and capital punishment and the law and has written extensively about criminal culpability and deathworthiness.

Dennis E. Curtis is Clinical Professor of Law Emeritus at Yale Law School.

Joseph L. Daly is Emeritus Professor of Law at Mitchell Hamline School of Law. He taught criminal law and procedure and worked for a year during a sabbatical in Regions Hospital in St Paul identifying legal issues involved in the treatment of the mentally ill.

Caroline Davidson is Associate Professor of Law at Willamette University, College of Law. She teaches criminal law, criminal procedure, and international criminal law and has written extensively about criminal law and human rights norms relating to criminal defendants.

Angela J. Davis is Professor of Law at the American University Washington College of Law where she teaches criminal law, criminal procedure, criminal defense: theory and practice, and criminal justice ethics: prosecution and defense. She is a former 
$10 \mathrm{a}$

director of the Public Defender Service for the District of Columbia.

LaJuana Davis is Professor of Law at Samford University, Cumberland School of Law. She teaches criminal law and disability law and has extensive experience litigating mental health claims in capital cases.

Christopher Dearborn is Clinical Professor of Law at Suffolk University Law School. He runs a criminal defense clinic and teaches in the areas of trial advocacy, criminal Law, and evidence.

Miguel de Figueiredo is Associate Professor of Law at the University of Connecticut School of Law. He teaches criminal law and criminal procedure.

Nora V. Demleitner is Roy L. Steinheimer Jr. Professor of Law at Washington and Lee University School of Law. She teaches and writes about criminal law and sentencing issues, and is the lead author of Sentencing Law and Policy (4th ed., 2018 Wolters Kluwer) and an editor of the Federal Sentencing Reporter.

Deborah W. Denno is Arthur A. McGivney Professor of Law and Founding Director of the Neuroscience and Law Center at the Fordham University School of Law. She teaches criminal law and criminal procedure and writes about various criminal law topics, including insanity.

Brett Dignam is Vice Dean of Experiential Education and Clinical Professor of Law at Columbia University Law School. She has clinics at both Yale (1992-2010) and Columbia (2010-present) Law Schools where she supervised law students who represent state and federal prisoners in federal court, many of whom have raised mental health defenses. 
$11 \mathrm{a}$

J. Amy Dillard is Associate Professor of Law at the University of Baltimore School of Law. She teaches criminal law and constitutional criminal procedure and has written extensively on competency and sanity issues in capital prosecutions.

Anthony Dillof is Professor of Law at Wayne State University Law School. He teaches criminal law and has written extensively about the conditions necessary for just criminal liability.

Robert D. Dinerstein is Professor of law and Director of the Disability Rights Law Clinic at American University, Washington College of Law. He teaches courses in and writes extensively on the rights of people with mental disabilities, including their treatment in the criminal justice system.

Mark M Dobson is Professor of Law and the CoDirector of the Criminal Justice Field Placement Clinic at the Shepard Broad College of Law of Nova Southeastern University. A former prosecutor, he teaches criminal law.

Don Doernberg is Professor of Law Emeritus at Pace University Elisabeth Haub School of Law and Visiting Professor of Law at McGeorge Law School, University of the Pacific.

Sharon Dolovich is Professor of Law and Director of the Prison Law and Policy Program at the UCLA School of Law. She has taught criminal law for almost 20 years.

David Dorfman is Professor of Criminal law and Criminal Procedure at the Elisabeth Haub School of Law at Pace University. He has been supervising attorney of the Pace Criminal Justice Clinic for the last seven years. 
$12 \mathrm{a}$

Joshua Dressler is Distinguished University Professor Emeritus at Ohio State University and the Frank R. Strong Chair in Law Emeritus at the Moritz College of Law at Ohio State University. He is the author of leading casebooks and treatises in criminal law and procedure.

Steven Duke is a Professor of Law at Yale Law School, where he teaches criminal procedure.

Martha-Grace Duncan is Professor of Law at Emory University School of Law, where she teaches criminal law and law and the unconscious mind. She has published extensively on criminal law, including works on remorse, prisons, and banishment.

David Eagleman, a neuroscientist, is Adjunct Professor at Stanford in the Department of Psychiatry \& Behavioral Sciences and is Director of the Center for Science and Law. He studies the intersection of brain science and the legal system, and has written extensively about criminal responsibility.

William A. Edmundson is Regents' Professor of Law and Professor of Philosophy at Georgia State University. He teaches criminal law and has written about moral and legal responsibility.

Nancy Ehrenreich is Professor of Law at the University of Denver Sturm College of Law, where she has taught criminal law for 30 years.

Tigran W. Eldred is Professor of Law at New England Law School. He teaches criminal law, criminal procedure, evidence and professional responsibility, and was formerly a public defender.

Jules Epstein is Professor of Law and Director of Advocacy Programs at the Temple Beasley School of Law. 
$13 a$

Margareth Etienne is Associate Dean and Professor of Law at the University of Illinois at UrbanaChampaign. She teaches criminal law, criminal procedure and sentencing law, and was formerly a criminal defense attorney.

Timothy H. Everett is Clinical Professor of Law and Pro Bono Coordinator at the University of Connecticut School of Law. He has taught criminal clinics and has taught criminal procedure and advanced criminal procedure.

Jeffrey Fagan is the Isidor and Seville Sulzbacher Professor of Law and Professor of Epidemiology at Columbia University. His research and scholarship examine criminal law and criminal procedure, including research on age and criminal responsibility.

Mary Falk is Professor of Law Emerita at Brooklyn Law School.

Katherine Hunt Federle is Joseph S. Platt--Porter Wright Morris and Arthur Professor of Law and Director of the Center for Interdisciplinary Law and Policy Studies at the Michael E. Moritz College of Law, Ohio State University.

Malcolm Feeley is Claire Sanders Clements Dean's Chair Emeritus in the Jurisprudence and Social Policy Program of the University of California School of LawBerkeley. He has taught courses on courts and social policy and the criminal process for the past 35 years.

Barry C. Feld is Centennial Professor of Law Emeritus at the University of Minnesota Law School, where he taught criminal procedure, criminal law and juvenile justice and has written extensively on adolescent criminal responsibility. 
$14 \mathrm{a}$

Linda C. Fentiman is Professor of Law at the Elisabeth Haub School of Law at Pace University. She teaches criminal law and mental disability law and has written about the insanity defense, competency to stand trial, criminal responsibility, and deterrence.

Keith A. Findley is Associate Professor of Law at the University of Wisconsin Law School. He teaches criminal procedure, evidence, wrongful convictions, and law and forensic science, and has written extensively about fairness in criminal prosecutions.

Claire O. Finkelstein is the Algernon Biddle Professor of Law, Professor of Philosophy and Faculty Director of the Center for Ethics and the Rule of Law at the University of Pennsylvania Law School. She teaches criminal law and has written extensively about criminal law and its theory.

George Fisher is the Judge John Crown Professor of Law at Stanford Law School. He is a former prosecutor and a longtime teacher of prosecution practice.

Alison Flaum is Clinical Professor of Law at Northwestern Pritzker School of Law. She has practiced and written about criminal law for over twenty years, with special focus on defendants with compromised decisional capacity.

Richard S. Frase is Benjamin N. Berger Professor of Criminal Law at the University of Minnesota Law School. He teaches criminal law and sentencing courses and has written extensively on retributive and other justifications for criminal punishment.

Lance Gable is Associate Professor of Law at Wayne State University Law School. He teaches public health law/bioethics and has written extensively about mental health and human rights. 
Kenneth S. Gallant is Ben J. Altheimer Distinguished Professor of Law Emeritus at the University of Arkansas at Little Rock Bowen School of Law.

Brian R. Gallini is Senior Associate Dean for Faculty at the University of Arkansas School of Law. He teaches a variety of doctrinal criminal courses and writes about criminal procedure.

Trevor Gardner is Assistant Professor of Law at the University of Washington. He teaches criminal Law and criminal procedure and has written extensively about the social construction of risk in relation to crime policy and criminal enforcement.

Norman M. Garland is Second Century Chair in Law and Professor of Law at Southwestern Law School

Brandon L. Garrett is L. Neil Williams Professor of Law at Duke University School of Law. His research and teaching interests include criminal procedure, wrongful convictions, habeas corpus, corporate crime, scientific evidence and constitutional law.

Stephen P. Garvey is Professor of Law at Cornell Law School. He teaches criminal law and has written about the insanity defense.

Sarah Gerwig-Moore is a Professor of Law at Mercer Law School. The founder of the Mercer Habeas Project, she teaches criminal law and procedure, and has written extensively about constitutional criminal law matters, including defenses related to mental illness and intellectual disability.

Mark Godsey is Carmichael Professor at the University of Cincinnati College of Law.

Phyllis Goldfarb is Associate Dean for Clinical Affairs and Jacob Burns Foundation Professor Emeritus of Clinical Law at George Washington University Law 
$16 a$

School. She previously directed a Criminal Justice Clinic at Boston College Law School for 21 years and taught courses in criminal procedure and the death penalty.

Sara Gordon is Associate Dean for Academic Affairs and an Associate Professor of Law at the William S. Boyd School of Law, University of Nevada Las Vegas, where she teaches evidence, criminal law, and mental health law.

Stuart Green is a Distinguished Professor of Law at Rutgers Law School. He teaches criminal law and has authored numerous books and articles on criminal responsibility.

Dermot Groome is Professor of Law at Penn State Dickinson Law. Prior to teaching criminal law and international criminal law, he handled several cases involving psychiatric defenses as both a domestic and international prosecutor.

Catherine M. Grosso is Professor of Law at Michigan State University. She teaches and researches criminal procedure and capital punishment.

Aya Gruber is Professor of Law at the University of Colorado Law School. She has written extensively about criminal law and responsibility.

Lawrence O. Gostin is the O'Neill Chair in Global Health Law and Director of the World Health Organization Collaborating Center on National \& Global Health Law at the Georgetown University Law Center. He directs the World Health Organization Center on National and Global Health Law.

Thomas Hagel is Professor of Law Emeritus at the University of Dayton School of Law. 
$17 \mathrm{a}$

Valerie P. Hans is Charles F. Rechlin Professor of Law at Cornell Law School, where she teaches courses on law and psychology. She has conducted research and written about popular misconceptions of the insanity defense.

Bernard E. Harcourt is Isidor and Seville Sulzbacher Professor of Law and Professor of Political Science at Columbia Law School and has written extensively on criminal law.

Leslie Harris is the Dorothy Kliks Fones Professor Emerita at the University of Oregon School of Law. She taught criminal law for more than 40 years.

Brandon Hasbrouck is Assistant Professor of Law at Washington and Lee University School of Law. He teaches criminal law and his research and writing focuses on criminal justice reform.

William E. Hellerstein is Professor of Law Emeritus at Brooklyn Law School, taught criminal procedure and constitutional law at Brooklyn Law School for 27 years. He won for the Legal Aid Society of New York the then landmark case in which the Second Circuit abandoned the M'Naghten test and adopted the ALI Model Penal Code for criminal insanity (United States v. Freeman, 357 F. 2d 606 (1966)).

Steven J. Heyman is Professor of Law at Chicago-Kent College of Law, Illinois Tech. He teaches criminal law and has written about issues of criminal law theory, including the legitimacy of capital punishment.

Mark J. Heyrman is Clinical Professor of Law at the University of Chicago Law School.

Janet C. Hoeffel is the Catherine D. Pierson Professor of Law at Tulane Law School. She teaches and writes 
$18 \mathrm{a}$

in the areas of criminal law and procedure, evidence and death penalty law.

Michael H. Hoffheimer is Professor of Law and Jamie L. Whitten Chair of Law and Government at the University of Mississippi. He has taught criminal law for over thirty years and published numerous articles on criminal law, legal history, and jury instructions.

Thaddeus Hoffmeister is Professor of Criminal Law at the University of Dayton School of Law and a Lieutenant Colonel in the Trial Defense Services of the National Guard.

Babe Howell is Professor of Law at CUNY School of Law.

John A. Humbach is Professor of Law at Elisabeth Haub School of Law at Pace University. He teaches in the area of criminal law and writes on criminal responsibility.

Heidi M. Hurd is Ross and Helen Workman Chair in Law, Professor of Philosophy and Co-Director of the Illinois Program in Law and Philosophy at the University of Illinois College of Law. She writes extensively on criminal law and moral theory.

Douglas Husak, a lawyer and philosopher, is Distinguished Professor of Philosophy at Rutgers University and teaches and writes about moral and criminal responsibility.

Renée McDonald Hutchins is the Dean and Joseph L. Rauh Jr. Chair of Public Interest Law at the University of the District of Columbia David A. Clarke School of Law. She teaches criminal procedure and has practiced as criminal appellate attorney for more than 25 years. 
$19 \mathrm{a}$

Chris Hutton is Professor of Law Emerita at the University of South Dakota School of Law. She taught criminal law, criminal procedure, and related subjects.

John V. Jacobi is Dorothea Dix Professor of Health Law and Policy at Seton Hall Law School. He teaches and publishes in the areas of mental health and disability law.

Eisha Jain is an Assistant Professor at the University of North Carolina School of Law. She teaches criminal law.

Eric S. Janus is Former President and Dean and Professor of Law, Mitchell Hamline School of Law. He teaches and writes in the fields of constitutional law and mental health law.

Judith Johnson is Professor of Law at Mississippi College School of Law. She has taught criminal law and criminal procedure for 35 years and has been chairing her state committee to reform the penal code for 20 years.

Sheri Lynn Johnson is James and Mark Flanagan Professor of Law and Assistant Director of the Cornell Death Penalty Project at Cornell Law School.

Thea Johnson is an Associate Professor of Law at the University of Maine School of Law. She teaches criminal law, criminal procedure and evidence

Lea Johnston is a University Term Professor at the University of Florida Levin College of Law, where she teaches criminal law, criminal procedure, and mental health law. Her scholarship focuses on the intersection of mental health, criminal procedure, and punishment. Irving Joyner is Professor of Law at North Carolina Central University School of Law where he teaches 
criminal procedure, race and the law, civil rights and criminal law.

Leonard Kaplan is Emeritus Professor of Law at the University of Wisconsin. He is past president of the International Academy of Law and Mental Health.

Leo Katz is Frank Carano Professor of Law at the University of Pennsylvania Law School. He teaches criminal law and has written books and articles about the field.

Lewis R. Katz is John C. Hutchens Professor of Law, Case Western Reserve University, where he has taught criminal law and procedure for over fifty years.

Anders Kaye is Associate Dean for Academic Affairs. Professor of Law and Co-Director of the Criminal Law Fellowship Program at Thomas Jefferson School of Law. He has written extensively about criminal responsibility and the capacities on which it depends.

Linda M. Keller is Interim Dean and Professor of Law at Thomas Jefferson School of Law, where she has taught criminal law for several years.

Joseph E. Kennedy is Martha Brandis Professor of Law at the University of North Carolina School of Law.

J.D. King is Clinical Professor of Law and the Director of the Criminal Justice Clinic at Washington and Lee University School of Law. He teaches criminal procedure, evidence, and professional responsibility and has written extensively about criminal law and procedure, including the representation of mentally ill clients facing criminal charges

Andrew King-Ries is Professor of Law at the Alexander Blewett III School of Law at the University of Montana. $\mathrm{He}$ teaches criminal law, criminal procedure, and 
$21 \mathrm{a}$

domestic violence and has published on the Montana law relating to mental disease or defect.

Kit Kinports is Professor of Law and Polisher Family Distinguished Faculty Scholar at Penn State Law. She teaches criminal law and has written extensively in that area.

Jeffrey L. Kirchmeier is Professor of Law at City University of New York School of Law. He teaches courses on criminal law and has written extensively on topics that include criminal responsibility, constitutional rights, and the Eighth Amendment.

Laird Kirkpatrick is Louis Harkey Mayo Research Professor at The George Washington University Law School.

Dorie Klein is Professor of Law at St. Mary's University School of Law, where she teaches mental health law, criminal law, and evidence.

Richard Klein is Bruce K. Gould Distinguished Professor of Law at Touro Law School. He has been a professor of criminal law for 35 years and has written extensively on criminal law issues.

Cecelia Klingele is Associate Professor of Law at the University of Wisconsin Law School. She teaches criminal law and procedure, criminal justice administration, and sentencing and corrections.

Issa Kohler-Hausmann is Associate Professor of Law and Sociology at Yale University. Her writing and research focus on criminal law, sociology of punishment, and parole law.

Margery Koosed is Professor emeritus at University of Akron School of Law where she taught criminal law and criminal procedure. 
$22 \mathrm{a}$

Joan H. Krause is Dan K. Moore Distinguished Professor of Law at the University of North Carolina Chapel Hill School of Law and Professor (Secondary Appointment), Social Medicine, UNC School of Medicine. She teaches criminal law and health law.

Tonya Krause-Phelan is Professor of Law at WMU Cooley Law School, where she teaches criminal law, criminal procedure, and trial skills. She also co-teaches the West Michigan Public Defender Clinic and prior to joining the faculty aw WMU Cooley, she was a practicing criminal defense attorney.

Alex Kreit is Professor of Law at Thomas Jefferson School of Law. He teaches criminal law and has writ;en a criminal law casebook, Criminal Law in Focus (Wolters Kluwer forthcoming 2019).

Susan Kuo is Professor of Law at the University of South Carolina School of Law, where she teaches criminal law and criminal procedure.

Christopher Kutz is C. William Maxeiner Distinguished Professor of Law at U.C. Berkeley, where he teaches and writes on criminal law and criminal responsibility.

Paul M. Kurtz is Associate Dean and J. Alton Hosch Professor Emeritus at the University of Georgia School of Law. He is the author of the standard treatise on Georgia Criminal Law.

Máximo Langer is Professor of Law and Faculty Director of the Criminal Justice Program at UCLA School of Law. He has been a professor at UCLA since 2003 and teaches criminal law, among other subjects.

Jennifer Laurin is the Wright C. Morrow Professor of Law at the University of Texas School of Law. She teaches and has written extensively in the fields of criminal law and criminal procedure. 
$23 a$

Tamara Rice Lave is Professor of Law at the University of Miami. She teaches and writes in the areas of criminal law, criminal procedure, evidence, and mental health.

Youngjae Lee is Professor of Law at Fordham University School of Law. Lee teaches criminal law and criminal procedure and has written extensively about criminal culpability.

Laurie L. Levenson is David W. Burcham Chair in Ethical Advocacy at Loyola Law School Los Angeles. A former Assistant United States Attorney who dealt with insanity defense cases, she writes extensively in criminal law.

Kate Levine is Assistant Professor of Law at St. John's University School of Law. She teaches criminal law and criminal procedure.

Martin L. Levine is UPS Foundation Chair in Law and Gerontology and Professor of Psychiatry and the Behavioral Sciences at the University of Southern California. He is a past Chair of the Law and Psychiatry Section of the Association of American Law Schools.

Rory K. Little is Joseph W. Cotchett Professor of Law at U.C. Hastings College of the Law. He teaches criminal law, criminal procedure, and constitutional law.

Paul Litton is the Associate Dean for Research and R.B. Price Professor of Law at the University of Missouri School of Law. He teaches criminal law and mental health law, and focuses his research on criminal responsibility.

Ken Levy is the Holt B. Harrison Professor of Law at LSU Law School. He writes in criminal theory and 
$24 \mathrm{a}$

teaches criminal law, advanced criminal law, international criminal law, and white collar criminal law.

Shaundra Kellam Lewis is a Professor of Law at Thurgood Marshall School of Law at Texas Southern University and a former federal and state Assistant Public Defender. She currently teaches criminal law and lawyering process.

Cortney E. Lollar is James \& Mary Lassiter Associate Professor at the University of Kentucky College of Law. She teaches criminal law, criminal procedure, and evidence, and her research and scholarly work often contemplate the psychological and mental health impacts of criminal laws and procedures.

Gary Lowenthal is Professor Emeritus at the Sandra Day O'Connor College of Law of Arizona State University.

David Luban is University Professor in Law and Philosophy at Georgetown University Law Center, and Distinguished Chair in Ethics at the Stockdale Center for Ethical Leadership, United State Naval Academy. His scholarship includes criminal law theory and ethics, and he teaches international and transnational criminal law.

Erik Luna is Amelia D. Lewis Professor of Constitutional \& Criminal Law at the Sandra Day O'Connor College of Law at Arizona State University. He teaches criminal law and criminal procedure and has written extensively on these subjects.

Paul Marcus is Haynes Professor of Law at the College of William and Mary. He teaches and writes in the areas of criminal law, criminal procedure and comparative law.

Elizabeth Phillips Marsh is Professor of Law Emerita at Quinnipiac University School of Law. 
$25 \mathrm{a}$

Katherine Mattes is Professor of the Practice and Director of the Criminal Justice Clinic at Tulane Law School and Adjunct Professor in the Forensic Psychiatry Department. She is the author of a manual for Louisiana lawyers and judges on the insanity defense and has taught numerous CLE's and judicial trainings on the insanity defense.

Sandra G. Mayson is Assistant Professor of Law at University of Georgia School of Law. Her scholarship explores the distinction between punishment and preventive restraint and highlights the role of moral culpability as a criterion for punishment.

Richard H. McAdams is the Bernard D. Meltzer Professor of Law at the University of Chicago and has taught criminal law for over 25 years.

Daniel S. McConkie is Associate Professor of Law at Northern Illinois University College of Law. He is a former Assistant United States Attorney, teaches courses in criminal law and procedure and writes primarily about criminal procedure.

Julie McConnell is Clinical Law Professor and Director of the Children's Defense Clinic at the University of Richmond School of Law. In addition to running the clinic, she teaches juvenile law and delinquency procedure, advanced clinical practice, and the science of false confessions.

Kris McDaniel-Miccio is Professor of Law at the University of Denver Sturm College of Law. She has been a Fulbright Scholar.

Kevin McMunigal is Professor of Law at Case Western Reserve University School of Law. He teaches criminal law, was formerly an Assistant United States Attorney, and is a Contributing Editor to CJ, the ABA Criminal Justice Section's quarterly magazine. 
$26 \mathrm{a}$

Jacqueline McMurtrie is Professor of Law at the University of Washington School of Law. She directs the Innocence Project Northwest Clinic, and has taught and written in the area of criminal law.

William G. Merkel is Associate Professor of Law at the Charleston School of Law. He is an expert on constitutional law, the Bill of Rights, and legal theory, and he formerly taught at Washburn Law School.

John Mikhail is Agnes N. Williams Research Professor and Associate Dean for Research and Academic Programs at Georgetown University Law Center, where he teaches constitutional law and criminal law, among other subjects. He has written extensively on moral psychology, cognitive science, and criminal law.

Colin Miller is Professor of Law at the University of South Carolina School of Law, where he teaches evidence and criminal law.

Eric J. Miller is a professor of law and Leo J. O'Brien Fellow at Loyola Law School, Los Angeles. Professor Miller has taught criminal law and has written extensively about criminal law and procedure.

David W Mills is Professor of Practice and Senior Lecturer (Continuing Appointment) at Stanford Law School.

Saira Mohamed is Professor of Law at the University of California, Berkeley, School of Law. She teaches and writes in the area of substantive criminal law.

John T. Monahan is the John S. Shannon Distinguished Professor of Law, Professor of Psychology and Professor of Psychiatry and Neurobehavioral Sciences at the University of Virginia. He teaches mental health law and has written extensively about criminal responsibility. 
$27 \mathrm{a}$

Michael S. Moore is Charles R. Walgreen, Jr. Chair for the University of Illinois' three campuses and is jointly appointed as professor of law in the College of Law and as a professor with the Center for Advanced Studies. He has written extensively on criminal law and mental health law, including the defense of legal insanity.

Stephen J. Morse is the Ferdinand Wakeman Hubbell Professor of Law and Professor of Psychology and Law in Psychiatry at the University of Pennsylvania and he is a board-certified forensic psychologist. He has written extensively on the insanity defense and on criminal responsibility generally.

Robert P. Mosteller is J. Dickson Phillips Distinguished Professor of Law at the University of North Carolina School of Law. He was a practicing criminal defense attorney and then taught criminal procedure and evidence and Duke and North Carolina.

Jeffrie G. Murphy is Regents' Professor of Law, Philosophy and Religious Studies at the Sandra Day O'Connor School of Law, Arizona State University. He has written extensively about the philosophy of crime and punishment and responsibility.

Dr Dora Nevares-Muniz is Distinguished Professor of Law at the Inter American University of Puerto Rico. She teaches criminal law, criminal procedure, juvenile justice, criminology, and biolaw, and is the author of various books on criminal law and chief drafter of the Puerto Rico Penal Code of 2004.

Samuel P. Newton is Assistant Professor of Law at the University of Idaho. He teaches criminal procedure and evidence and has published articles related to criminal law.

Kenneth B. Nunn is Professor of Law, Associate Director Criminal Justice Center, and Assistant 
$28 \mathrm{a}$

Director of the Center on Children and Families at the University of Florida Levin College of Law. He teaches criminal law and procedure and writes about criminal law reform and racial justice.

Sean D. O'Brien is Professor of Law at the University of Missouri-Kansas City School of Law. He teaches criminal law and mental health law and has written articles and book chapters on standards for conducting forensic mental health investigations and assessments.

Anne Olesen is Professor of Clinical Law at the George Washington University Law School and directs the Criminal Appeals and Post-Conviction Services Clinic. She previously worked in the Civil Rights Division of the Department of Justice where she litigated cases enforcing the right to mental health treatment in prisons and jails.

Jennifer Oliva is Associate Professor of Law and member of the Center for Health \& Pharmaceutical Law \& Policy at the Seton Hall University School of Law. She teaches health law and evidence courses, including neuroscience and the law.

William Wesley Patton, a psychiatrist, is Lecturer in Law at the University of Southern California Gould School of Law and at the UCLA David Geffen School of Medicine, Department of Psychiatry. For more than 30 years, he has taught and published articles on criminal responsibility and on the psychological effects of the legal system on those charged with criminal offenses.

Gary Peller is Professor of Law at Georgetown University Law Center.

Michael L. Perlin is Professor Emeritus of Law at New York Law School, where he taught criminal law, criminal procedure, and multiple mental disability law 
$29 \mathrm{a}$

courses. He writes extensively about the insanity defense and all aspects of criminal law and procedure as it affects persons with serious mental disabilities.

LeRoy Pernell is past Dean and Professor of Law at Florida A. \& M. University College of Law. He has taught, written, and advocated law reform extensively in the area of criminal procedure and mental health

Samuel H. Pillsbury is Professor of Law and Frederick J. Lower Fellow at Loyola Law School, Los Angeles, where he teaches courses in criminal law and criminal responsibility relating to mental disorders. He also works as a chaplain in the Twin Towers Correctional Facility in Los Angeles which is the largest provider of in-patient mental health services in the West.

Ellen S. Podgor is Gary R. Trombley Family WhiteCollar Crime Research Professor of Law at Stetson University College of Law. She teaches criminal law, criminal procedure - adjudication, and white collar criminal law.

Daniel D. Polsby is past dean and Professor of Law at George Mason University and was the Kirkland \& Ellis Professor of Law at Northwestern University. He teaches criminal law.

Robert A Pugsley is Emeritus Professor of Criminal Law at Southwestern Law School.

Amanda C. Pustilnik is Professor of Law at the University of Maryland School of Law and a program director of the Center for Law, Brain, and Behavior at Massachusetts General Hospital. She was the first fellow in Law \& Applied Neuroscience at Harvard Law School and has written extensively on the legal relevance of cognitive neuroscience. 
$30 \mathrm{a}$

Intisar Rabb is Professor of Law at Harvard Law School. He teaches and writes about criminal law.

Gerald S. Reamey is Professor of Law at St. Mary's University School of Law, where he has taught criminal law and constitutional criminal procedure for thirty-seven years. He has published several books and numerous law review and journal articles on the subject of criminal responsibility.

Richard E. Redding is the Ronald D. Rotunda Distinguished Professor of Jurisprudence at the Fowler School of Law at Chapman University and Professor of Psychology and Education at Chapman University. He teaches criminal law and mental health law and has written extensively about forensic mental health issues, including the insanity defense.

Charles J. Reid, Jr. is Professor of Law at the University of St. Thomas. He teaches criminal law and jurisprudence.

Judith Resnik is Arthur Liman Professor of Law at Yale Law School, where she teaches criminal justice.

L. Song Richardson is Dean and Chancellor's Professor of Law at UC Irvine School of Law. Her areas of expertise include criminal law and criminal procedure.

Judith L. Ritter is Distinguished Professor of Law, Director of the Taishoff Advocacy, Technology, and Public Service Institute, and Director of the Widener Criminal Defense Clinic at Widener University Delaware Law School. She teaches criminal law.

Ira P. Robbins is Barnard T. Welsh Scholar and Professor of Law at American University, Washington College of Law. He has taught criminal law for more than forty years and has written extensively about mens rea and related issues. 
$31 \mathrm{a}$

Kalyani Robbins is a Professor of Law at Loyola University Chicago School of Law. Professor Robbins is a former ADA for New York County and teaches and writes about criminal law.

Anna Roberts is Professor of Law at St. John's University School of Law, where she teaches criminal law and evidence.

Dorothy E. Roberts is George A. Weiss University Professor of Law \& Sociology and Raymond Pace \& Sadie Tanner Mossell Alexander Professor of Civil Rights at the University of Pennsylvania. She has taught and written extensively in criminal law and related fields for thirty-one years.

Paul H. Robinson is Colin S. Diver Professor of Law at the University of Pennsylvania. He teaches criminal law and has written numerous books, including a casebook and treatise, and articles on criminal law.

Addie C. Rolnick is a Professor of Law at the University of Nevada, Las Vegas, William S. Boyd School of Law. She teaches criminal law.

Charles H. Rose, a retired Army Judge Advocate, is Professor of Law at Stetson University and the incoming Dean of the Ohio Northern University Wayne W. Pettit School of Law. He teaches and writes in the areas of criminal procedure, evidence and trial advocacy, and has published numerous articles and texts in these areas.

Leslie Rose is Professor Emerita at Golden Gate, where she continues to teach criminal procedure. She was a staff attorney at the Office of the California State Public Defender, which handled complex criminal appeals, death penalty, and habeas corpus cases. 
$32 \mathrm{a}$

Clifford Rosky is Professor of Law at the University of Utah S.J. Quinney College of Law, where he teaches criminal law.

Jacqueline E. Ross is Prentice H. Marshall Professor of Law and Director of the Program in Comparative Criminal Procedure and Policing at the University of Illinois College of Law. She teaches criminal Law, with coverage of mental health issues, and writes about criminal responsibility.

Paul Rothstein is Professor of Law at Georgetown. He has taught criminal law, was Advisor to both Senate and House subcommittees of their Judiciary Committees attempting recodification of the entire Federal Criminal Code, and has written extensively about culpability and the defenses.

Susan D. Rozelle is Professor of Law at Stetson University College of Law. She teaches criminal law, evidence, criminal procedure: adjudication, and a seminar in criminal responsibility and has written extensively about the insanity defense and related issues.

David Rudovsky is Senior Fellow at the University of Pennsylvania Law School. He teaches and writes in criminal law and procedure and has extensive practice experience in those areas.

Howard M. Rubin is Professor of Law Emeritus at DePaul College of Law. He taught professional responsibility, directed the DePaul Legal Clinic for over 30 years, taught the Criminal Appeals Clinic, and was Associate Dean for the Lawyering Skills courses.

Elyn R. Saks is Orrin B. Evans Distinguished Professor of Law, Psychology, and Psychiatry and the Behavioral Sciences at the University of Southern California Gould School of Law as well as Faculty 
$33 a$

Director of the USC Saks Institute for Mental Health Law, Policy, and Ethics. She writes extensively in the area of law and mental health, having published over 50 articles and five books.

Lupe S. Salinas is Professor of Law at Texas Southern University Thurgood Marshall Law School. He is a retired criminal court judge and now teaches criminal law and procedure.

Alan Saltzman is retired Professor of Law. He taught criminal law at the University of Oklahoma, the University of Nebraska and The University of Detroit Mercy.

Barry C. Scheck is Professor of Law and Co-Founder of the Innocence Project at the Benjamin N. Cardozo School of Law. He has taught and practiced criminal law, including involvement in insanity and related diminished capacity cases.

Albert E. Scherr is Professor of Law and Chair of the International Criminal Law \& Justice Program at the University of New Hampshire School of Law. He teaches constitutional criminal procedure and evidence.

Susan R. Schmeiser is Professor of Law at the University of Connecticut School of Law. She teaches criminal law, mental health law and family law, and her scholarship addresses intersections between law and the mental health professions.

Robert F. Schopp is Robert J. Kutak Professor of Law, Professor of Psychology, and Professor of Philosophy at the University of Nebraska. His work focuses on the significance of psychological impairment for the justification of various forms of criminal and civil interventions into ordinarily protected liberties. 
$34 \mathrm{a}$

Stephen J. Schulhofer is Robert B. McKay Professor of Law at New York University. He has taught criminal law for more than forty-five years, written extensively on criminal law and procedure, and is the co-author if one of the nation's leading casebooks on criminal law.

Judith A.M. Scully is Professor of Law at Stetson University College of Law and is Co-Director of the Social Justice Advocacy Concentration Program. She teaches and writes in the areas of criminal and juvenile law, with special emphasis on issues of race.

Elisabeth Semel is Clinical Professor of Law at UC Berkeley School of Law where she is the founding Director of the Death Penalty Clinic. In that capacity and before joining the faculty, she has been engaged extensively in issues involving criminal and mental health law.

Steven Semeraro is Professor of Law at Thomas Jefferson School of Law. He has practiced, taught and written about criminal law and procedure for over 30 years.

Bijal Shah is Associate Professor of Law at Arizona State University, Sandra Day O'Connor College of Law. He teaches criminal law, and has both litigated and written policy on criminal matters as they concern immigration.

Laurie Shanks is Clinical Professor of Law Emerita at Albany Law Schoo. She has been a criminal defense attorney for 40 years.

James Shellenberger is Professor of Law at Temple University Beasley School of law, where he has taught several criminal law and criminal procedure courses for 35 years. Before joining the Temple faculty, he was, among other things, an Assistant District Attorney in Philadelphia and Chief Staff Counsel for the 
$35 \mathrm{a}$

Pennsylvania Supreme Court's Criminal Procedural Rules Committee.

Karl Shoemaker is Professor of History and Law at the University of Wisconsin, Madison. He has taught the history of criminal law for 17 years.

Dawinder S. Sidhu is visiting professor at the University of Maryland Francis King Carey School of Law. He teaches and writes in the areas of criminal law and criminal sentencing and founded a facility that serves individuals suffering from addiction and co-occurring mental health disorders.

David M. Siegel is Professor of Law and Director, Center for Law and Social Responsibility at New England Law School. He teaches criminal law and procedure and has written extensively on mental health issues in the criminal process.

Jonathan S. Simon is Adrian A. Kragen Professor of Law and Director of the Center for the Study of Law and Society at the University of California Berkeley. He teaches classes on criminal law and punishment, has co-taught a mental health and criminal justice reform seminar and has published extensively on punishment in contemporary society.

Kenneth W. Simons is Chancellor's Professor of Law and Philosophy at the University of California, Irvine School of Law. He teaches criminal law, has taught seminars on crime and punishment, and has written extensively about criminal law culpability and responsibility.

Eric S. Sirulnik is Professor of Law Emeritus of the George Washington University School of Law, where he taught criminal law, criminal procedure, the administration of criminal justice, drugs and the law, and trial advocacy. He also served as Director of the 
$36 \mathrm{a}$

Community Legal Clinics and Associate Dean for Clinical Affairs.

Christopher Slobogin is the Milton Underwood Professor of Law at Vanderbilt University. He is the lead author of the leading casebook in mental health law and writes extensively about criminal law, criminal procedure and mental health law.

Abbe Smith is Professor of Law, Director of the Criminal Defense \& Prisoner Advocacy Clinic, and CoDirector of the E. Barrett Prettyman Fellowship Program at Georgetown University. She teaches criminal law and procedure and legal ethics.

Stephen F. Smith is Professor of Law at the University of Notre Dame. He teaches criminal law and procedure and has written extensively about the need to limit punishment in accordance with offenders' moral blameworthiness.

Matthew Steffey is Professor of Law at Mississippi College School of Law. He teaches criminal law and constitutional law and has recently written on criminal procedure.

John A. Strait is Emeritus Professor of Law and Professional Ethics Counsel at Seattle University School of Law.

Carol Steiker is Professor of Law at Harvard Law School. She teaches criminal law, criminal procedure, and capital punishment law, and has written extensively in the broad field of criminal justice.

Jordan Steiker is the Judge Robert Parker Chair and Director of the Capital Punishment Center at the University of Texas School of Law. 
$37 \mathrm{a}$

Kate Stith is Lafayette S. Foster Professor of Law at Yale Law School. She teaches and writes about criminal law.

Donald H. Stone is Professor of Law and Director of the Mental Health Law Clinic at the University of Baltimore School of Law.

Irwin P. Stotzky is Professor of Law at the University of Miami School of Law.

John Kelly Strader is Professor of Law at Southwestern Law School. He teaches and writes principally in the area of criminal law.

Mark A. Summers is Professor of Law at Barry University Dwayne O. Andreas School of Law. He teaches criminal law, criminal procedure and evidence.

Ellen Y. Suni is Dean Emerita and Professor of Law at University of Missouri-Kansas City School of Law. She has taught criminal law for more than 25 years.

Kim Taylor-Thompson is Professor of Clinical Law at New York University School of Law. She teaches criminal law and has written about criminal responsibility.

John Teeter is Professor of law at St. Mary's University School of Law and has been teaching criminal law for more than thirty years.

Edward H. Telfeyan is Professor of Lawyering Skills at the McGeorge School of Law University of the Pacific. He teaches criminal law defenses and was formerly a criminal defense attorney.

Joseph Thai is the Watson Centennial Chair in Law at the University of Oklahoma College of Law

Peter N. Thompson is Emeritus Professor of Law at Mitchell Hamline School of Law. 
$38 \mathrm{a}$

Rachel Van Cleave is Professor of Law and Former Dean at Golden Gate University, School of Law. She teaches constitutional law, criminal procedure and comparative criminal justice and is a two-time US Fulbright Scholar awardee: in 1996 at the Italian Constitutional Court and in 2020 at the Corte Suprema di Cassazione, Rome.

Michael Vitiello is Professor of Law at McGeorge School of Law. He writes extensively about criminal law.

Cynthia V. Ward is Professor of Law at William and Mary Law School, where she teaches and writes in criminal law and psychology \& law.

D. Kelly Weisberg is Professor of Law at Hastings College of the Law, University of California. She teaches domestic violence law and juvenile justice., and writes extensively on domestic violence law.

Charles D. Weisselberg is the Shannon C. Turner Professor at the University of California, Berkeley, School of Law. Weisselberg teaches criminal law and criminal procedure, and previously practiced mental health law.

Lois A. Weithorn is a Professor of Law and Harry \& Lillian Hastings Research Chair at University of California Hastings College of the Law. She teaches criminal law and mental health law.

Peter K. Westen is Frank C. Millard Professor of Law Emeritus at the University of Michigan. He has written extensively about criminal law and criminal law theory.

David B Wexler is Professor of Law at the University of Puerto Rico and Distinguished Research Professor of Law Emeritus at the University of Arizona. He has taught and written about criminal law and mental 
$39 \mathrm{a}$

health law and now focuses on those areas through his work in therapeutic jurisprudence.

James Q Whitman is Ford Foundation Professor of Comparative and Foreign Law at Yale University. He has written extensively about criminal law, including numerous books and articles.

Donald E. Wilkes, Jr., is Professor of Law Emeritus, University of Georgia School of Law, where he taught criminal procedure for 37 years and criminal law for 20 years.

Pamela A. Wilkins is Associate Professor of Law at the University of Detroit Mercy School of Law. She teaches criminal law and some of her scholarship has focused on mental illness and the death penalty.

Kenneth Williams is Professor of Law at South Texas College of Law. He teaches criminal law and procedure and evidence, and has written a book and numerous law review articles on issues related to capital punishment and the mental health issues related to capital punishment.

Jonathan Witmer-Rich is Joseph C. Hostetler-Baker Hostetler Professor of Law at Cleveland-Marshall College of Law, Cleveland State University. He teaches criminal law and criminal procedure and has published on blameworthiness in the criminal law.

Steven Zeidman is Professor of Law at CUNY School of Law, where he teaches Criminal Procedure and directs a Criminal Defense Clinic. His scholarly interests include the constitutional and ethical dimensions of assistance of counsel. 
$40 \mathrm{a}$

Adnan A. Zulfiqar is an Assistant Professor of Law at Rutgers Law School where his research and teaching focus on criminal law and procedure. He has helped draft and implement multiple criminal codes, each including an insanity defense. 